\title{
Nota
}

\section{Imantodes inornatus (Boulenger, 1886) (Squamata: Dipsadidae): expansion of known range and first records from the Magdalena River valley, Colombia}

Imantodes inornatus (Boulenger, 1886) (Squamata: Dipsadidae): expansión del rango de la distribución conocida y primeros registros del valle del río Magdalena, Colombia

Román F. Díaz-Ayala, Julián A. Rojas-Morales, Juan C. Zuluaga-Isaza y Viviana A. Ramírez-Castaño

\begin{abstract}
The first report of the Speckled Blunt-headed Tree Snake (Imantodes inornatus) is presented for the Magdalena River valley, from the departments of Antioquia, Bolívar, Boyacá and Caldas in Colombia. Since these records correspond to the biogeographic Magdalena province, the known range for the species is expanded. In Colombia, this is a trans-Andean species found from the Pacific rainforests of the Chocó region, through the northern portion of the Western and Central Andean ranges, to the middle Magdalena River valley.
\end{abstract}

Keywords. Biogeographic provinces. Geography. Species distribution. Speckled Blunt-headed Tree Snake.

\section{Resumen}

Se registra por primera vez la serpiente de árbol cabeza moteada (Imantodes inornatus) en el valle del río Magdalena en los departamentos de Antioquia, Bolívar, Boyacá y Caldas, en Colombia. Estos registros corresponden a la provincia biogeográfica del Magdalena, lo que aumenta el área de distribución conocida. En Colombia, esta especie es un elemento transandino que cruza las selvas tropicales del Pacífico de la región chocoana, a través de la porción septentrional de las cordilleras Occidental y Central hasta el valle medio del río Magdalena.

Palabras clave. Distribución de especies. Geografía. Provincias biogeográficas. Serpiente arborícola de cabeza roma moteada.

\section{Introduction}

Accurate information on species distribution and natural history is the basis for biodiversity management and conservation (González-Maya et al., 2014), for it is a key attribute for assessing the status of threatened species (IUCN, 2012). With over 270 snake species, Colombia is one of the richest countries in snake fauna in the world, surpassed only by Mexico and Brazil (http:// 
www.reptile-database.org, Lynch et al., 2014). However, knowledge about biological aspects such as diversity patterns, distribution, natural history, and conservation status of Colombian snakes is still incipient and poorly represented in scientific literature. Although herpetological collections from the late nineteenth and early twentieth centuries have provided a large collection of snakes from almost all Colombian eco-regions (Lynch et al., 2014), reviews have been made only on a few species $(<10 \%)$, generating major challenges in terms of snake conservation (Lynch, 2012, 2015).

The Neotropical Speckled Blunt-headed Tree Snake of the genus Imantodes (Linnaeus, 1758), are nocturnal and arboreal species. Eight nominal species of Imantodes are currently known. They are widely distributed from Central to South America (Myers, 1982; Torres-Carvajal et al., 2012; Medina-Rangel et al., 2018). These snakes have arboreal habits with morphological features adapted to this microhabitat, including thin bodies and enlarged heads with protuberant eyes, which differs significantly from the neck (Savage, 2002; Torres-Carvajal et al., 2012). There are seven species of Imantodes in Colombia, which are: I. cenchoa (Linnaeus, 1758); I. chocoensis TorresCarvajal et al. 2012; I. gemmistratus (Cope, 1861); I. guane Missassi \& Prudente 2015; I. inornatus (Boulenger, 1896); I. lentiferus (Cope, 1894); I. phantasma Myers 1982 (Medina-Rangel et al., 2018). The genus Imantodes is distributed throughout the country, from sea level to $2300 \mathrm{~m}$ of elevation, but certain eco-regions are poorly represented with few published data, such as the Orinoco savannas and the Amazonian rainforest (see Rojas-Morales et al., 2014 for I. cenchoa), biogeographic provinces of Orinoquia, Guayana and Amazonia (sensu Hernandez-Camacho et al., 1992).

Imantodes inornatus differs from its congeners by having yellowish dorsum and small black spots on the head, which often form very narrow crosslines, usually 1 preocular or rarely 2 , fewer than 220 ventrals and fewer than 140 subcaudal scales (Myers, 1982; Savage, 2002). This species ranges from Nicaragua in Central America, to Ecuador in northern South America, being an arboreal dwelling species in lowland wet forests, with some records in pre-montane wet forest (Myers, 1982; Savage, 2002; Köller, 2003). In Colombia, this species is known in the west (Pacific slope) of the Cordillera Occidental between $0-880 \mathrm{~m}$ of elevation, Chocó-Magdalena province (sensu Hernandez-Camacho et al., 1992), in the departments of Chocó and Valle del Cauca (Sánchez-C. et al., 1995; Castaño-Mora et al., 2004; Castro-Herrera \& Vargas-Salinas, 2008; Cardona-Botero et al., 2013; Echavarría-R. et al., 2016).

Based on individuals recently recorded in the field, review of scientific literature and data of herpetological collections, we present the first records of I. inornatus in the Magdalena River valley, which corresponds to the trans-Andean valley that separates Eastern and Central ranges (Cordillera Oriental and Cordillera Central) in central Colombia.

\section{Materials and methods}

Records of I. inornatus were taken from fieldwork completed in 2014, in the area of Miel I hydroelectric project. Also, we reviewed information and specimens from different herpetological collections and museums: AMNH (American Museum of Natural History, New York), MHN-UC (Museo de Historia Natural Universidad de Caldas, Manizales, Caldas), MHUA (Museo de Herpetología Universidad de Antioquia, Medellín, Antioquia), ICN (Instituto de Ciencias Naturales de la Universidad Nacional, Bogotá, Cundinamarca), UIS (Colección de Herpetología Universidad Industrial de Santander, Bucaramanga, Santander), CD (Colección docencia Universidad del Valle, Cali, Valle del Cauca) y COL200CH-M (Colección Científica de Referencia Zoológica de la Universidad Tecnológica del Chocó - Herpetología, Quibdó, Chocó) (Table 1). 


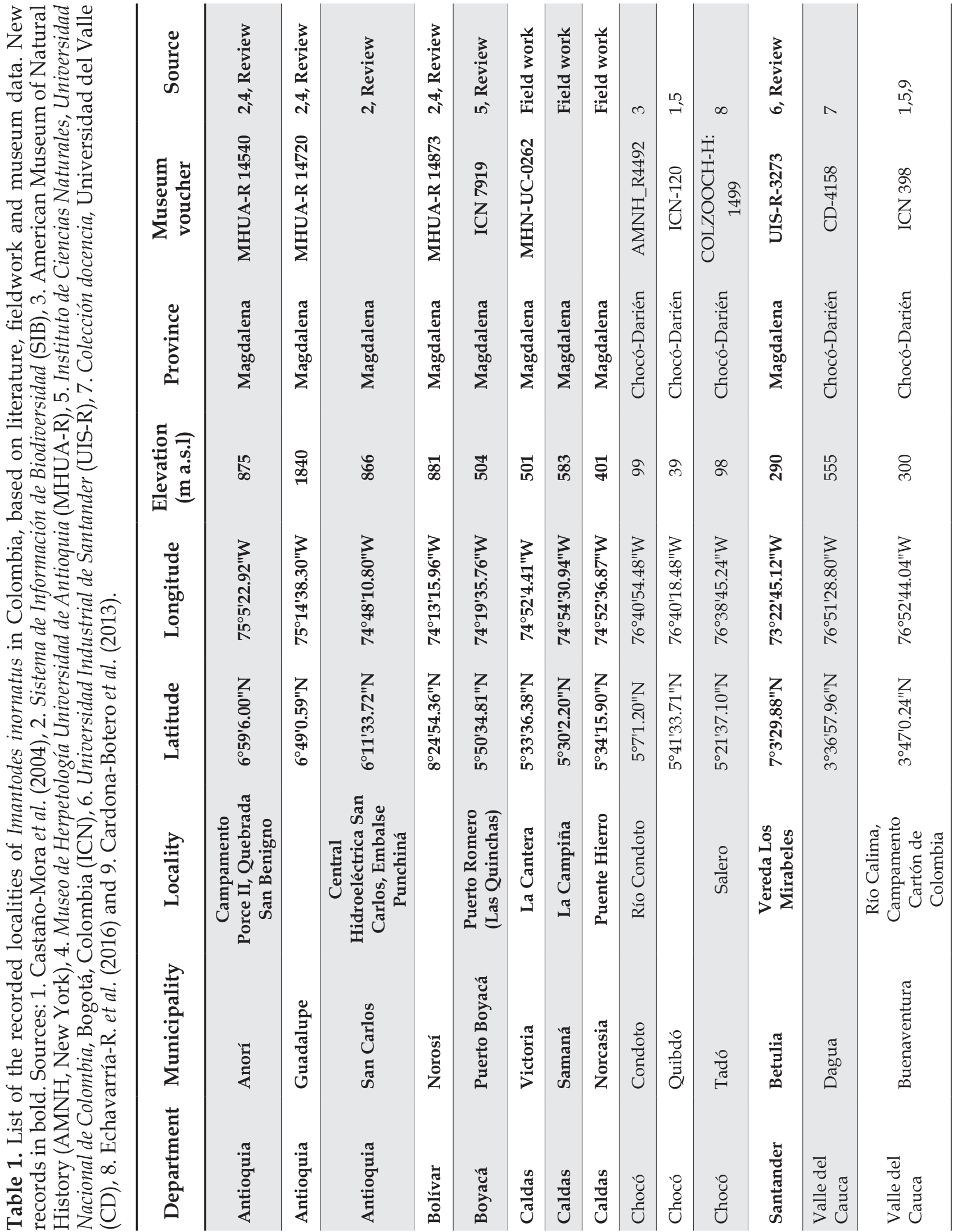




\section{Results and discussion}

We obtained nine records of $I$. inornatus: three from the field and six from specimens in herpetological collections (Figure 1, Table 1). Fieldwork specimens: On 12 March 2014 at 19:17 $\mathrm{h}$, an individual of I. inornatus (590 mm snout vent length [SVL], $213 \mathrm{~mm}$ tail length [TL], Figure 2A) was found moving across a bush of ferns $90 \mathrm{~cm}$ height from the ground, at "bosque La Campiña", Confines village, municipality of Samaná, department of Caldas. A second specimen was observed on 19 July 2014 at 09:03 h, moving in riparian vegetation in "Puente Hierro" vereda La Quiebra, Norcasia municipality, department of Caldas (Figure 2B). A third specimen (632 mm SVL, 231 mm TL, MHN-UC 0262, Figure
2C) was found on 31 October 2014 at 21:47 $\mathrm{h}$ in "La Cantera", El Bosque village, municipality of Victoria, department of Caldas. This individual was observed on the base of a submerged plant in a pond border; it was collected under permit resolution number 164 of 2014, issued by CORPOCALDAS (Autonomous Regional Corporation of Caldas), and it was deposited in the Museo de Historia Natural of the Universidad de Caldas (MHN-UC 0262). This specimen presents 17-17-15 dorsal scales, 196 ventrals, 105 subcaudals, eight supralabials (3-5 contacting the orbit), nine infralabials (1-5 contacting shinshields), one preocular, and one postocular scales.

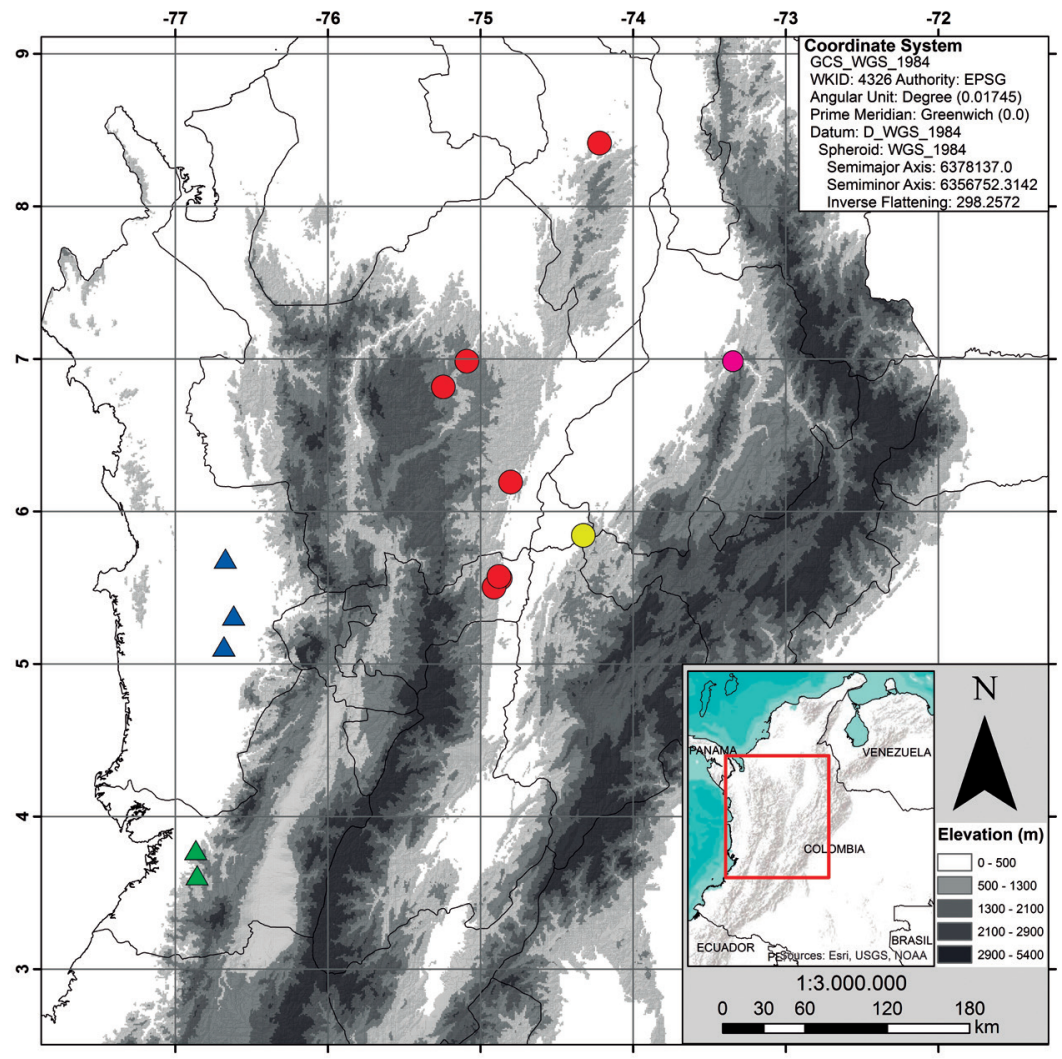

Figure 1. Known distribution of Imantodes inornatus in Colombia based on voucher specimens. Triangles depict the previous knowns records. Dots depict new records. The colors indicate districts into the Chocó-Magdalena biogeographic province sensu Hernandez-Camacho et al (1992): green triangles (Mikay district), blue triangles (Alto Atrato-San Juan district), red circles (Nechí district), yellow circles (Carare district), and violet circles (Lebrija district). 

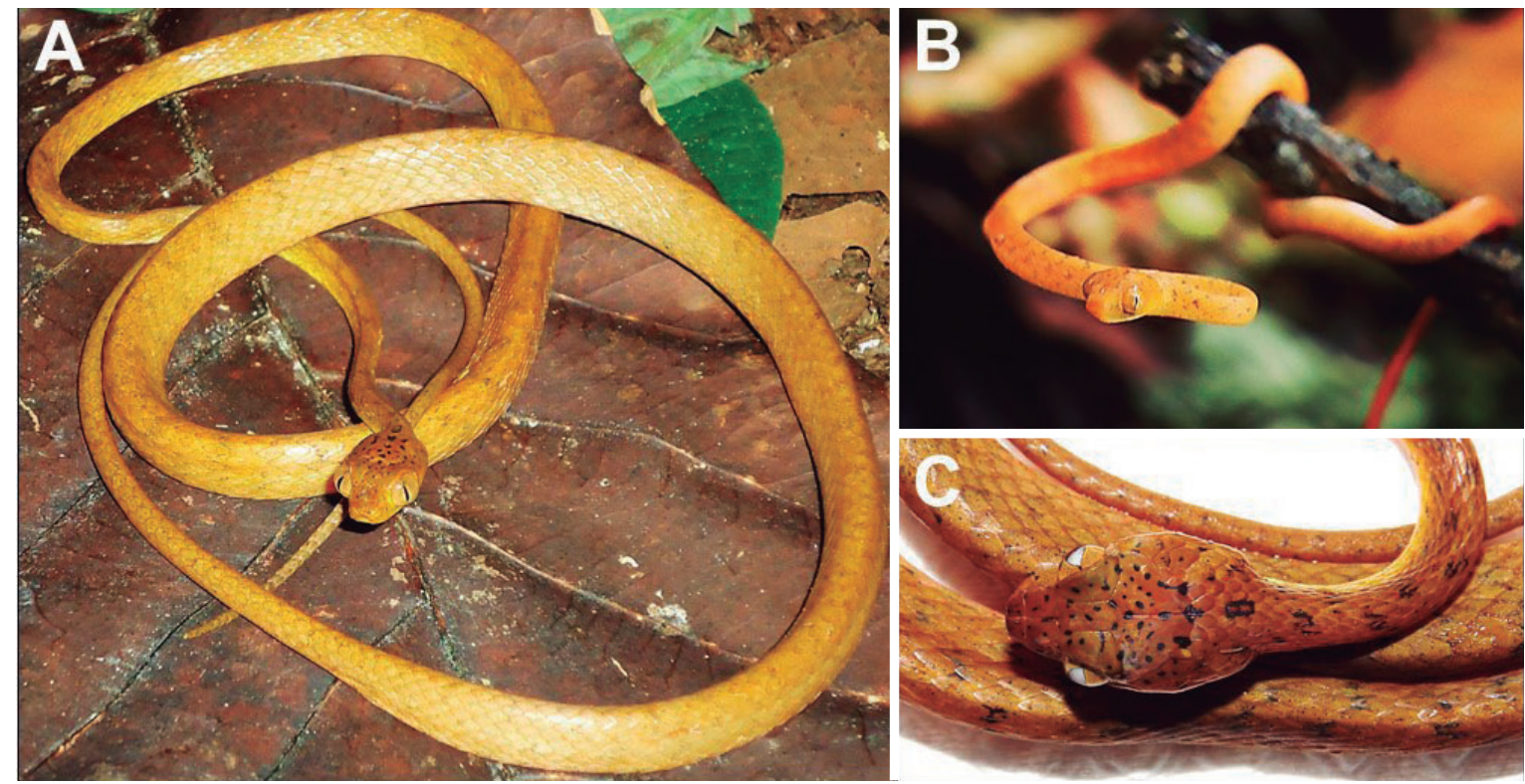

Figure 2. Imantodes inornatus from the middle Magdalena river valley, in the department of Caldas, Colombia. A) Live specimen (590 mm SVL, not collected) from "La Campiña", Confines village, municipality of Norcasia. B) Live specimen (not collected) from "Puente Hierro", La Quiebra village, municipality of Norcasia. C) Collected female (632 mm SVL, MHN-UC 0262) from "La Cantera" El Bosque village, municipality Victoria (Caldas, Colombia). Photographs: A) Román F. Díaz, B) Anyinson López, C) Julián Andrés Rojas.

The distribution of Imantodes inornatus corresponds to the region known as the Chocó Biogeográfico (Biogeographical Chocó) from the Northwest of Honduras, to Colombia and Ecuador in northern South America. Another reptile species of different lineages of Squamata show this distribution pattern (i. e. Rhinobothryum bovalli [Serpentes: Dipsadidae], Diploglossus monotropis [Sauria: Diploglossidae], Tantilla reticulata [Serpentes: Dipsadidae], Ninia teresitae [Serpentes: Dipsadidae]) (Savage, 2002; CastañoMora et al., 2004; Rojas-Morales, 2012; DíazAyala et al., 2015; Angarita-Sierra \& Lynch, 2017). The distribution of $I$. inornatus in the middle Magdalena River valley, particularly in the Nechí, Carare and Lebrija districts (ChocóMagdalena biogeographic province), supports the known shared distribution of some amphibians and reptiles between the Pacific and middle Magdalena humid forests, as has been discussed by other authors (Hernandez-Camacho et al.,
1992; Acosta-Galvis et al., 2006; Angarita-Sierra and Lynch, 2017; Gutiérrez-C. \& Arredondo-S., 2007; Rojas-Morales, 2012; Díaz-Ayala et al., 2015).

Accelerated habitat loss and degradation by different activities in the middle Magdalena River valley (i. e. cattle rising, illegal crops, and energy projects), have modified the natural landscape pattern. Monitoring wildlife populations that inhabit these areas, including rarely seen and poorly known species such as snakes, is very important.

\section{Acknowledgements}

We thank Universidad de Caldas and ISAGEN (contract 47/180) for partially funding fieldwork associated with this note. To Lauren Vonnahme and Margaret Arnold for providing information of specimens under their care (American Museum of Natural History). To Anyinson López, Elson 
Meneses Pelayo, Andres Gómez Figueroa and Wilmar Bolívar for providing some records. Jóse Rancés Caicedo-Portilla and two anonymous reviewers improved an earlier version of this manuscript.

\section{Literature cited}

Acosta-Galvis, A. R., Huertas-Salgado, C. \& Rada, M. (2006). Aproximación al conocimiento de los anfibios en una localidad del Magdalena medio (departamento de Caldas, Colombia). Revista de la Academia Colombiana de Ciencia Exactas, Físicas y Naturales, 30, 291-303.

Angarita-Sierra, T \& Lynch, J. D. (2017). A new species of Ninia (Serpentes: Dipsadidae) from Chocó-Magdalena biogeographical province, western Colombia. Zootaxa, 4244, 478-492.

Castaño-Mora, O.V., Cárdenas-Arévalo, G., Hernández-Ruiz, E. J. \& Castro-Herrera, F. (2004). Catálogo de Reptiles en el Chocó Biogeográfico. In Rangel, J. O. (Ed.). Colombia Diversidad Biótica IV. El Chocó Biogeográfico. Pp: 615-631. Bogotá: Universidad Nacional de Colombia.

Castro-Herrera, F. \& Vargas-Salinas, F. (2008). Anfibios y reptiles en el departamento del Valle del Cauca, Colombia. Biota Colombiana, 9, 251277.

Cardona-Botero, V. E., Viáfara-Vega, R. A., Valencia-Zuleta, A., Echeverry-Bocanegra, A., Hernández-Córdoba, O. D., Jaramillo-Martínez, A. F., Galvis-Cruz, R., Gutiérrez, J. A. \& CastroHerrera, F. (2013). Diversidad de la herpetofauna en el Valle del Cauca (Colombia): Un enfoque basado en la distribución por ecorregiones, altura y zonas de vida. Biota Colombiana, 14, 157-234.

Díaz-Ayala, R. F., Gutiérrez-C., P. D., VásquezCorrea, A. M. \& Caicedo-Portilla, J. R. (2015). New records of Diploglossus monotropis (Kuhl 1820) (Squamata: Anguidae) from Urabá and Magdalena River valley, Colombia, with an updated geographic distribution map. Checklist, 11, 1-7.
Echavarría-R., J. D., Rentería-M., L. E. \& Rengifo-M, J.T. (2016). New record of Imantodes chocoensis (Squamata: Dipsadidae) in the biogeographyc Choco Colombian. Revista Colombiana de Ciencia Animal, 8, 14-19.

González-Maya, J. F., Castañeda, F., González, R., Pacheco, J. \& Ceballos, G. (2014). Distribution, range extension, and conservation of the endemic black-headed bushmaster (Lachesis melanocephala) in Costa Rica and Panama. Herpetological Conservation Biology, 9, 369-377.

Gutiérrez-C., P. D. \& Arredondo-S, J. C. (2007). Leposoma southi Ruthven and Gaige. 1924. A new record to the fauna of Antioquia (Colombia). Herpetozoa, 20, 77-79.

Hernández-Camacho, J., Hurtado-Guerra, A., Ortiz-Quijano, R. \& Walshburger, T. (1992) Unidades biogeograficas de Colombia. In Halffter, G. (Ed.). La diversidad Biológica de Ibreroamerica I. México: Instituto de Ecología A.C. 204 pp.

IUCN. (2012). Red List Categories and Criteria: Version 3.1. Second edition. Gland, Switzerland and Cambridge, UK. 34 pp.

Köller, G. (2003). Reptiles de Centroamérica. Offenbach, Germany: Herpeton, Verlag. 367 pp.

Lynch, J. D. (2012). El contexto de las serpientes de Colombia con un análisis de las amenazas en contra de su conservación. Revista de la Academia Colombiana de Ciencia Exactas, Físicas y Naturales, 36, 435-449.

Lynch, J. D., Angarita-Sierra, T. \& Ruiz-Gómez, F.A. (2014). Programa Nacional para la Conservación de las Serpientes Presentes en Colombia. Bogotá D.C., Colombia: Ministerio de Ambiente y Desarrollo Sostenible. 128 pp.

Lynch, J. D. (2015). The role of plantations of the african palm (Elaeis guineensis Jacq.) in the conservation of snakes in Colombia. Caldasia, 37, 169-182.

Medina-Rangel, G. F., Cárdenas-Arévalo, G. \& Rentería-M, L. E. (2018). Rediscovery and first 
record of the Phantasma Tree Snake, Imantodes phantasma Myers, 1982 (Serpentes, Colubridae), in Colombia. Checklist, 14(1), 237-242.

Myers, C. M. (1982). Blunt-headed vine snakes (Imantodes) in Panama, Including a new species and other revisionary notes. American Museum Novitates, 1-50.

Rojas-Morales, J. A. (2012). On the geographic distribution of the false coral snake, Rhinobothryum bovallii (Serpentes: Dipsadidae), in Colombia - a biogeographical perspective. Salamandra, 48, 243-248.

Rojas-Morales, J. A., Arias-Monsalve, H. F. \& Mendoza-Mendoza, I. (2014). Geographical distribution of Imantodes cenchoa (Serpentes: Dipsadidae) in Colombia: Filling gaps for the montane cloud forests of northern south America. Herpetotropicos, 10, 09-16.

Sánchez-C., H., Castaño-M., O. \& Cárdenas-A, G. (1995). Diversidad de los reptiles en Colombia. In Rangel-Ch., J. O. (Ed.). Colombia Diversidad Biótica I. Pp. 277-326. Bogotá: Instituto de Ciencias Naturales-Universidad Nacional de Colombia-Inderena.

Savage, J. M. (2002). The Amphibians and Reptiles of Costa Rica: A Herpetofauna between Two Continents, between Two Seas. Illinois, Chicago: The University of Chicago Press. 934 pp.

Torres-Carvajal, O., Yánez-Muñoz, M. H., Quirola, D., Smith, E. N. \& Almendáriz, A. (2012). A new species of blunt-headed vine snake (Colubridae, Imantodes) from the Chocó region of Ecuador. ZooKeys, 244, 91-110.
Román F. Díaz-Ayala

Universidad de Caldas,

Facultad de Ciencias Exactas y Naturales

Manizales, Colombia

romanfelipe_17@hotmail.com

Julián A. Rojas-Morales

Natural Seeds Alliance

Manizales, Colombia

julian.herpetologia@gmail.com

Juan C. Zuluaga-Isaza

Universidad de Caldas,

Facultad de Ciencias Exactas y Naturales

Manizales, Colombia

juan_ah25@hotmail.com

Viviana A. Ramírez-Castaño

Universidad de Caldas,

Facultad de Ciencias Exactas y Naturales

Manizales, Colombia

vivianaramirezc@gmail.com
Imantodes inornatus (Boulenger, 1886)

(Squamata: Dipsadidae): expansion of known range and first records from the Magdalena River valley, Colombia

Citación del artículo: Díaz-Ayala, R. F., RojasMorales, J. A., Zuluaga-Isaza, J. C. y RamírezCastaño, V. A. (2018). Imantodes inornatus (Boulenger, 1886) (Squamata: Dipsadidae): expansion of known range and first records from the Magdalena River valley, Colombia. Biota Colombiana, 19(1), 219-225. DOI: 10.21068/c2018. v19n01a14.

Recibido: 15 de noviembre de 2017

Aprobado: 12 de marzo de 2018 